\title{
Effects of acute infusion of erythropoietin on paradoxical responses of growth hormone to thyrotropin-releasing hormone in acromegalic patients
}

\author{
Juan J Díez, Pedro Iglesias, Julia Sastre and Antonio Gómez-Pan \\ Department of Endocrinology, Hospital La Paz, Madrid, Spain \\ (Correspondence should be addressed to J J Díez, Travesía Téllez 8, 4R, 28007 Madrid, Spain; Email: mibarsd@infomed-dental.com)
}

\begin{abstract}
Objective: Our aim has been to evaluate the effects of i.v. infusion of recombinant human erythropoietin (rhEPO) on the responses of growth hormone (GH), prolactin (PRL) and thyrotropin (TSH) to thyrotropin-releasing hormone (TRH) stimulation in acromegalic patients.

Methods: We studied 16 patients ( 8 females, aged 29-68 years) with active acromegaly and 12 control subjects ( 7 females, 24-65 years). All participants were tested with TRH (400 $\mu \mathrm{g}$ i.v. as bolus) and with TRH plus rhEPO (40 U/kg at a constant infusion rate for $30 \mathrm{~min}$, starting $15 \mathrm{~min}$ before TRH injection) on different days. Blood samples were obtained between -30 and $120 \mathrm{~min}$ for GH and PRL determinations, and between -30 and $90 \mathrm{~min}$ for TSH determinations. Hormone responses were studied by a time-averaged (area under the secretory curve (AUC)) and time-independent (peak values) analysis.

Results: Twelve patients exhibited a paradoxical GH reaction after TRH administration with great interindividual variability in GH levels. When patients were stimulated with rhEPO plus TRH there were no changes in the variability of GH responses or in the peak and AUC for GH secretion. Infusion with rhEPO did not induce any significant change in GH secretion in normal subjects. Baseline and TRH-stimulated PRL concentrations in patients did not differ from those values found in controls. When TRH was injected during the rhEPO infusion, a significant $(P<0.05)$ increase in PRL concentrations at 15-120 min was found in acromegalic patients. Accordingly, the PRL peak and the AUC for PRL secretion were significantly increased in patients. Infusion with rhEPO had no effect on TRH-induced PRL release in control subjects. Baseline TSH concentrations, as well as the TSH peak and the AUC after TRH, were significantly lower in patients than in controls. Infusion with rhEPO modified neither the peak TSH reached nor the AUC for TSH secretion after TRH injection in acromegalic patients and in healthy volunteers.

Conclusion: Results in patients with acromegaly suggest that (i) the paradoxical GH response to TRH is not modified by rhEPO infusion, (ii) rhEPO has no effect on TRH-induced TSH release, and (iii) acute rhEPO administration increases the TRH-induced PRL release in acromegalic patients.
\end{abstract}

European Journal of Endocrinology 143 203-211

\section{Introduction}

It is well known that patients with active acromegaly show not only elevated growth hormone $(\mathrm{GH})$ and insulin-like growth factor-I (IGF-I) concentrations, but also derangements in $\mathrm{GH}$ secretion. Some of the alterations found in acromegaly include the incomplete suppression of GH levels after glucose loading (1), a decrease after administration of L-dopa (2) or galanin (3), and the so-called paradoxical responses to stimuli (such as thyrotropin-releasing hormone (TRH) $(2,4)$, gonadotropin-releasing hormone $(\mathrm{GnRH})(5)$ and corticotropin-releasing hormone (CRH) (6)) that do not release $\mathrm{GH}$ in normal subjects.

Nowadays, erythropoietin is considered as one of the several growth factors and functional similarities between erythropoietin and IGF-I molecules have been reported (7). Recombinant human erythropoietin (rhEPO) has been used in the last decade for the treatment of anemia in patients with end-stage renal disease. Several lines of evidence have suggested that therapy with rhEPO is associated with changes in hypothalamic-hypophyseal function in these patients. The effects of rhEPO administration on GH secretion have been studied by several workers, both after chronic treatment and in acute experimental protocols. Ramírez et al. (8) reported that the basal elevation of $\mathrm{GH}$ was normalized in hemodialysis patients after correction of anemia with rhEPO therapy. A significant potentiation of the $\mathrm{GH}$ response to growth hormone-releasing 
hormone (GHRH) after chronic rhEPO administration has been found in uremic patients undergoing hemodialysis (9) or continuous ambulatory peritoneal dialysis (10). Potentiation of GH responses to GHRH has also been obtained in a group of hemodialyzed patients after acute administration of an i.v. rhEPO infusion (11). Furthermore, the paradoxical response of GH to TRH that is frequently associated with uremia has been reported to be abolished after correction of the anemia with chronic rhEPO therapy (12), and acutely administered rhEPO has been shown to inhibit this abnormal $\mathrm{GH}$ release in patients with chronic renal failure (13).

Together, these data suggest that rhEPO might exert some effects at hypothalamic or pituitary level, and support the hypothesis that this peptide can modulate the response of somatotrope cells through a mechanism other than increased oxygen supply. Based on this background, the present study was performed with the aim of evaluating the influence of acutely administered rhEPO on the responses of GH to TRH stimulation in a group of patients with active acromegaly. We have also assessed the responses of prolactin (PRL) and thyrotropin (TSH) after stimulation with TRH and with rhEPO plus TRH.

\section{Subjects and methods}

\section{Patients}

Sixteen patients with active acromegaly and 12 healthy volunteers, whose main clinical and analytical characteristics are shown in Table 1, were studied. The study was approved by the local ethical committee, and informed consent was obtained from all participants before testing. There were no significant differences between acromegalic patients and control subjects in terms of gender distribution, age, systolic and diastolic blood pressure, hemoglobin concentrations, hematocrit values, or plasma concentrations of urea, creatinine, glucose, cholesterol, triglycerides, albumin and free thyroxine. Patients showed a higher body mass index, higher levels of plasma phosphorus concentrations and lower levels of calcium and total protein than controls. Diagnosis of active acromegaly was based on clinical features and the presence of elevated random $\mathrm{GH}$ concentrations. At the time of the study all patients showed IGF-I concentrations higher than $450 \mu \mathrm{g} / \mathrm{l}$ and $\mathrm{GH}$ levels higher than $2 \mu \mathrm{g} / \mathrm{l}$ after a $75 \mathrm{~g}$ oral glucose load. On magnetic resonance imaging, nine of the patients had a macroadenoma ( $>10 \mathrm{~mm}$ in diameter) and seven had an intrasellar microadenoma. All patients presented with pure GH-secreting tumors. Three of them had been treated by trans-sphenoidal incomplete surgical resection of the pituitary adenoma, performed at least 6 months before this study. One patient was treated by trans-sphenoidal surgery followed by external conventional radiotherapy seven
Table 1 Clinical and analytical data on acromegalic patients and control subjects (means \pm s.E.M.).

\begin{tabular}{|c|c|c|}
\hline Parameter & $\begin{array}{c}\text { Patients } \\
(n=16)\end{array}$ & $\begin{array}{c}\text { Controls } \\
(n=12)\end{array}$ \\
\hline \multicolumn{3}{|l|}{ Clinical data } \\
\hline Age (years) & $49.88 \pm 2.95$ & $44.67 \pm 4.05$ \\
\hline Gender (male/female) & $8 / 8$ & $7 / 5$ \\
\hline Weight $(\mathrm{kg})$ & $79.14 \pm 2.73$ & $67.53 \pm 3.38^{b}$ \\
\hline Body mass index $\left(\mathrm{kg} / \mathrm{m}^{2}\right)$ & $29.40 \pm 1.06$ & $24.11 \pm 0.56^{b}$ \\
\hline Systolic blood pressure (mmHg) & $140.3 \pm 4.2$ & $127.9 \pm 3.9$ \\
\hline Diastolic blood pressure $(\mathrm{mmHg})$ & $85.3 \pm 3.3$ & $79.2 \pm 1.4$ \\
\hline Time of evolution (years) & $5.38 \pm 0.78$ & \\
\hline Diabetes mellitus (yes/no) & $4 / 12$ & $0 / 12$ \\
\hline Hypertension (yes/no) & $4 / 12$ & $0 / 12$ \\
\hline Tumoral status (macro/micro) & $9 / 7$ & - \\
\hline \multicolumn{3}{|l|}{ Analytical data } \\
\hline Hematocrit (\%) & $41.8 \pm 1.2$ & $43.4 \pm 1.4$ \\
\hline Hemoglobin $(\mathrm{g} / \mathrm{dl})$ & $14.0 \pm 0.4$ & $14.4 \pm 0.5$ \\
\hline Urea $(\mathrm{mg} / \mathrm{dl})$ & $36.0 \pm 3.1$ & $32.5 \pm 2.8$ \\
\hline Creatinine (mg/dl) & $0.95 \pm 0.08$ & $0.96 \pm 0.04$ \\
\hline Glucose (mg/dl) & $110.8 \pm 9.9$ & $92.8 \pm 3.5$ \\
\hline Cholesterol (mg/dl) & $218.8 \pm 14.2$ & $216.2 \pm 8.4$ \\
\hline Triglycerides (mg/dl) & $124.3 \pm 16.5$ & $104.8 \pm 7.4$ \\
\hline Calcium (mg/dl) & $9.5 \pm 0.1$ & $9.7 \pm 0.1^{\mathrm{a}}$ \\
\hline Phosphorus (mg/dl) & $4.3 \pm 0.2$ & $3.4 \pm 0.1^{c}$ \\
\hline Albumin $(g / l)$ & $43.3 \pm 0.6$ & $45.0 \pm 1.0$ \\
\hline Total protein $(g / l)$ & $66.9 \pm 0.8$ & $71.0 \pm 1.0^{\mathrm{b}}$ \\
\hline Free thyroxine (ng/dl) & $1.42 \pm 0.07$ & $1.32 \pm 0.05$ \\
\hline $\mathrm{GH}$ after glucose* $(\mu \mathrm{g} / \mathrm{l})$ & $15.0 \pm 4.9$ & \\
\hline IGF-I $(\mu \mathrm{g} / \mathrm{l})$ & $860.8 \pm 79.4$ & \\
\hline
\end{tabular}

Comparisons between patients and controls (Mann-Whitney U test): ${ }^{\mathrm{a}} P<0.05 ;{ }^{\mathrm{b}} P<0.01 ;{ }^{\mathrm{c}} P<0.001$.

${ }^{*} \mathrm{GH}$ measurement after $75 \mathrm{~g}$ oral glucose load.

years before the study. Bromocriptine was used in three patients and octreotide in one. Drug therapy was stopped at least three weeks before the study. Nine patients had received no therapy for acromegaly. Four patients had non-insulin-dependent diabetes mellitus controlled by diet $(n=2)$ or oral drugs $(n=2)$, and four patients had hypertension controlled with anti-hypertensive therapy. Suppressive doses of levothyroxine were employed in one patient who had a previous history of papillary thyroid carcinoma. This patient was excluded from TSH evaluation.

\section{Study design}

Endocrine tests were begun at $0900 \mathrm{~h}$ after an overnight fast, with the subjects recumbent. An indwelling catheter was placed in a forearm vein and kept patent with a slow infusion of $0.9 \% \mathrm{NaCl}$. Each subject received TRH (TRH Prem, Zyma-Frumtost, Gland, Switzerland), $400 \mu \mathrm{g}$ i.v. as a bolus at time 0 . Blood samples were collected at $-30,0,15,30,60,90$ and $120 \mathrm{~min}$. In another experiment, 5 days apart, the subjects were tested with TRH plus rhEPO (Erantin, Boehringer Mannheim, Mannheim, Germany) at $40 \mathrm{IU} / \mathrm{kg}$ body weight, infused at a constant rate for $30 \mathrm{~min}$, starting $15 \mathrm{~min}$ before TRH administration. The tests with TRH 
alone and TRH plus rhEPO were performed in a randomized order. In all blood samples, plasma $\mathrm{GH}$ and PRL concentrations were assessed. TSH concentrations were measured between -30 and $90 \mathrm{~min}$. Blood hemoglobin concentrations and hematocrit values, and serum concentrations of urea, creatinine, calcium, phosphorus, total protein, albumin, cholesterol, triglycerides and free thyroxine, were also determined at time 0 in one of the experiments.

\section{Hormone assays}

Blood samples were centrifuged immediately and the plasma stored at $-20^{\circ} \mathrm{C}$ until assayed. Human plasma $\mathrm{GH}$ concentrations were determined by using an automated immunoenzymatic assay (AIA 1200, Tosoh, Tokyo, Japan). Maximal intra-assay and interassay coefficients of variation were 5.4 and 3.3\% respectively. The sensitivity of the GH assay was $0.1 \mu \mathrm{g} / \mathrm{l}$. Plasma TSH and PRL concentrations were also determined using the Tosoh immunoenzymatic assay. For TSH assay, the sensitivity was $0.06 \mu \mathrm{U} / \mathrm{ml}$ and the maximal intra-assay and inter-assay coefficients of variation were 3.3 and 3.4\% respectively. For PRL assay, the sensitivity and maximal intra-assay and inter-assay coefficients of variation were, respectively, $1 \mu \mathrm{g} / \mathrm{l}, 6 \%$ and $4.5 \%$. Free thyroxine was measured by commercially available immunoenzymatic assay kits (AIA-PACK FT4, Tosoh, Tokyo, Japan) that use the automated system AIA-1200. Maximal intra-assay and inter-assay coefficients of variation were 9.6 and $7.7 \%$ respectively. The sensitivity of FT4 assay was $0.1 \mathrm{ng} / \mathrm{dl}$. The plasma IGF-I assay was performed after an ethanol-acid extraction by means of a commercially available radioimmunoassay kit (Nichols Institute, San Juan Capistrano, CA, USA). Maximal intra-assay and inter-assay coefficients of variation were 3.0 and $8.4 \%$ respectively, and the sensitivity of the assay was $13.5 \mu \mathrm{g} / \mathrm{l}$. Blood hemoglobin concentrations and hematocrit values were measured in a Coulter counter, and the serum chemistry determinations were made using an automated multichannel analyser.

\section{Statistical analysis}

Results are expressed as means \pm s.E.M. The hormonal secretory responses were studied by a time-averaged (area under the curves) and time-independent (peak values) analysis. Peak hormonal concentration was considered in each test as the maximum level reached by GH, PRL or TSH regardless of the time taken to do so. The areas under the secretory curve (AUC) for GH and PRL were calculated between 0 and $120 \mathrm{~min}$ by a trapezoidal method. For TSH, the AUC were calculated between 0 and $90 \mathrm{~min}$. The statistical evaluation of the GH, PRL and TSH responses after TRH alone and after TRH plus rhEPO administration within each group of subjects studied (acromegalic patients and healthy volunteers) was performed by means of the Wilcoxon signed-rank test. For comparisons between patients and controls, the Mann-Whitney U test was employed. The differences were considered to be significant at a $P$ level less than 0.05 .

\section{Results \\ Growth hormone responses}

As expected, baseline GH concentrations were significantly higher in patients than in controls $(10.6 \pm 3.8 \mathrm{vs}$ $1.3 \pm 0.3 \mu \mathrm{g} / \mathrm{l}, \quad \mathrm{P}<0.001$; Table 2). A paradoxical response of $\mathrm{GH}$ in the TRH test was considered to be present when the GH concentration increased > $100 \%$ from baseline values (2). According to this criterion, all but four patients exhibited paradoxical $\mathrm{GH}$ reactions after TRH injection. GH concentrations after stimulation showed a marked interindividual variability, ranging from 4 to $380 \mu \mathrm{g} / \mathrm{l}$ (mean $41.2 \pm 23.0$ ) (Fig. 1A). When patients were stimulated by rhEPO plus TRH there was no significant modification in the variability of GH responses (Fig. 1A) or in the peak concentrations reached $(45.5 \pm 25.4 \mu \mathrm{g} / \mathrm{l})$. In consequence, the AUC of $\mathrm{GH}$ after rhEPO plus TRH did not differ from that found after stimulation with TRH alone (Table 2).

In contrast to these findings in acromegalic patients, most of the normal subjects exhibited a flat response to both TRH and rhEPO plus TRH infusion (Fig. 1A). On average, peak $\mathrm{GH}$ concentrations in healthy subjects were $2.0 \pm 0.5 \mu \mathrm{g} / \mathrm{l}$ after $\mathrm{TRH}$ and $2.2 \pm 0.8 \mu \mathrm{g} / \mathrm{l}$ $(P>0.05)$ after rhEPO plus TRH. In a similar way, rhEPO infusion did not induce any significant change in the AUC of GH secretion in response to TRH in normal subjects.

We have also studied GH responses in male and female patients and controls separately. We could not find any significant change, induced by rhEPO infusion, in GH peaks or AUC elicited by TRH stimulation when analyzing responses in male and in female subjects.

\section{Prolactin responses}

Baseline PRL concentrations in patients ranged from 1 to $28 \mu \mathrm{g} / \mathrm{l}$ (mean $10.0 \pm 2.1$ ), i.e. no one had overt hyperprolactinemia. TRH injection was followed by a prompt rise in PRL concentrations that reached a peak of $27.6 \pm 4.7 \mu \mathrm{g} / \mathrm{l}$ at $15-30 \mathrm{~min}$. We could not find any significant differences between patients and control subjects in terms of baseline and TRH-stimulated PRL concentrations (Table 2). Nevertheless, when TRH was injected during the rhEPO infusion, a significant increase in the maximum PRL concentration was observed in acromegalic patients $(36.3 \pm 4.8 \mu \mathrm{g} / \mathrm{l}$, $P<0.01)$ in relation to the PRL peak after TRH alone. Analysis of the concentration versus time curves showed that rhEPO infusion induced a significant increase in PRL levels 15 to $120 \mathrm{~min}(P<0.05)$ after 
Table 2 Baseline and stimulated GH, PRL and TSH concentrations in acromegalic patients and control subjects (means \pm S.E.M.).

\begin{tabular}{|c|c|c|c|}
\hline Parameter & Units & $\begin{array}{l}\text { Patients } \\
(n=16)\end{array}$ & $\begin{array}{c}\text { Controls } \\
(n=12)\end{array}$ \\
\hline $\begin{array}{l}\text { GH responses } \\
\text { Baseline concentrations } \\
\text { Peak concentrations after TRH } \\
\text { Peak concentrations after rhEPO + TRH } \\
\text { AUC after TRH } \\
\text { AUC after rhEPO + TRH }\end{array}$ & $\begin{array}{l}\mu \mathrm{g} / \mathrm{l} \\
\mu \mathrm{g} / \mathrm{l} \\
\mu \mathrm{g} / \mathrm{l} \\
\mu \mathrm{g} . \mathrm{h} / \mathrm{l} \\
\mu \mathrm{g} . \mathrm{h} / \mathrm{l}\end{array}$ & $\begin{array}{l}10.6 \pm 3.8 \\
41.2 \pm 23.0 \\
45.5 \pm 25.4 \\
62.8 \pm 36.8 \\
66.4 \pm 36.7\end{array}$ & $\begin{array}{l}1.3 \pm 0.3^{\mathrm{c}} \\
2.0 \pm 0.5^{\mathrm{c}} \\
2.2 \pm 0.8^{\mathrm{c}} \\
2.6 \pm 0.4^{\mathrm{c}} \\
2.3 \pm 0.2^{\mathrm{c}}\end{array}$ \\
\hline $\begin{array}{l}\text { PRL responses } \\
\text { Baseline concentrations } \\
\text { Peak concentrations after TRH } \\
\text { Peak concentrations after rhEPO + TRH } \\
\text { AUC after TRH } \\
\text { AUC after rhEPO + TRH }\end{array}$ & $\begin{array}{l}\mu \mathrm{g} / \mathrm{l} \\
\mu \mathrm{g} / \mathrm{l} \\
\mu \mathrm{g} / \mathrm{l} \\
\mu \mathrm{g} / \mathrm{l} \\
\mu \mathrm{g} . \mathrm{h} / \mathrm{l}\end{array}$ & $\begin{array}{l}10.0 \pm 2.1 \\
27.6 \pm 4.7 \\
36.3 \pm 4.8^{\star} \\
36.5 \pm 5.6 \\
51.1 \pm 6.9^{\star}\end{array}$ & $\begin{array}{r}6.9 \pm 0.9 \\
37.1 \pm 4.9 \\
41.9 \pm 8.9 \\
44.4 \pm 5.3 \\
50.3 \pm 9.2\end{array}$ \\
\hline $\begin{array}{l}\text { TSH responses§ } \\
\text { Baseline concentrations } \\
\text { Peak concentrations after TRH } \\
\text { Peak concentrations after rhEPO + TRH } \\
\text { AUC after TRH } \\
\text { AUC after rhEPO + TRH }\end{array}$ & $\begin{array}{l}\mathrm{mU} / \mathrm{l} \\
\mathrm{mU} / \mathrm{l} \\
\mathrm{mU} / \mathrm{l} \\
\mathrm{mU} \cdot \mathrm{h} / \mathrm{l} \\
\mathrm{mU} \cdot \mathrm{h} / \mathrm{l}\end{array}$ & $\begin{array}{l}0.52 \pm 0.10 \\
4.85 \pm 0.63 \\
5.10 \pm 0.55 \\
4.88 \pm 0.69 \\
5.23 \pm 0.59\end{array}$ & $\begin{array}{l}1.05 \pm 0.17^{\mathrm{b}} \\
8.83 \pm 1.12^{\mathrm{b}} \\
8.43 \pm 1.13^{\mathrm{a}} \\
9.24 \pm 1.44^{\mathrm{b}} \\
9.06 \pm 1.39^{\mathrm{a}}\end{array}$ \\
\hline
\end{tabular}

Comparisons between patients and controls (Mann-Whitney $U$ test): ${ }^{\mathrm{a}} P<0.05 ;{ }^{\mathrm{b}} P<0.01 ;{ }^{\mathrm{c}} P<0.001$. Comparisons within each group (responses after TRH and after rhEPO plus TRH; Wilcoxon test): ${ }^{*} P<0.01$.

$\S$ Patients, $n=15$.

TRH injection (Fig. 1B). Accordingly, the AUC of prolactin were significantly higher when patients were stimulated with rhEPO plus TRH $(51.1 \pm 6.9 \mu \mathrm{g} . \mathrm{h} / \mathrm{l})$ than when TRH was injected alone (36.5 $\pm 5.6 \mu \mathrm{g} . \mathrm{h} / \mathrm{l}$, $P<0.01)$. All but three patients exhibited increases in their TRH-induced peaks of PRL concentration when stimulated with rhEPO. These increments ranged from 5.3 to $300 \%$ (mean $65.7 \pm 24.1 \%$ ). When studying the correlation between baseline PRL levels and the percentage of change in peak prolactin concentrations induced by rhEPO we found a non-significant relationship $(r=-0.328$, N.S.).

In the group of 12 control subjects, the PRL peak was also elicited at 15-30 min of TRH administration and reached a value of $37.1 \pm 4.9 \mu \mathrm{g} / \mathrm{l}$ when TRH was administered alone and $41.9 \pm 8.9 \mu \mathrm{g} / \mathrm{l}$ when $\mathrm{TRH}$ was injected during the rhEPO infusion $(P>0.05)$. No significant differences were observed between PRL responses to TRH (estimated by peaks and AUC) in the presence or in absence of rhEPO in normal subjects.

When PRL responses were classified according to gender, we observed that the significant increase $(P<0.05)$ in PRL peaks and AUC after rhEPO infusion was present in both male and female acromegalic patients. No significant changes were found in male or female healthy volunteers (Table 3).

\section{Thyrotropin responses}

Baseline TSH concentrations in acromegalic patients were lower than those found in control subjects

Table 3 PRL responses after TRH and rhEPO plus TRH in acromegalic patients and control subjects classified according to gender (means \pm S.E.M.).

\begin{tabular}{|c|c|c|c|c|c|}
\hline \multirow[b]{2}{*}{ Parameter } & \multirow[b]{2}{*}{ Units } & \multicolumn{2}{|c|}{ Males } & \multicolumn{2}{|c|}{ Females } \\
\hline & & $\begin{array}{l}\text { Patients } \\
(n=8)\end{array}$ & $\begin{array}{c}\text { Controls } \\
(n=7)\end{array}$ & $\begin{array}{l}\text { Patients } \\
(n=8)\end{array}$ & $\begin{array}{l}\text { Controls } \\
(n=5)\end{array}$ \\
\hline Baseline concentration & $\mu \mathrm{g} / \mathrm{l}$ & $9.5 \pm 3.0$ & $5.6 \pm 0.7$ & $10.5 \pm 3.0$ & $8.8 \pm 1.5$ \\
\hline Peak concentration after TRH & $\mu \mathrm{g} / \mathrm{l}$ & $19.4 \pm 3.7$ & $32.6 \pm 5.2$ & $35.8 \pm 7.8$ & $43.4 \pm 9.0$ \\
\hline Peak concentration after rhEPO $+\mathrm{TRH}$ & $\mu \mathrm{g} / \mathrm{l}$ & $26.6 \pm 5.3^{*}$ & $41.0 \pm 14.3$ & $46.0 \pm 6.6^{*}$ & $43.2 \pm 9.7$ \\
\hline AUC after TRH & $\mu \mathrm{g} \cdot \mathrm{h} / \mathrm{l}$ & $27.8 \pm 6.0$ & $37.7 \pm 4.8$ & $45.3 \pm 8.7$ & $53.8 \pm 9.7$ \\
\hline AUC after rhEPO + TRH & $\mu \mathrm{g} \cdot \mathrm{h} / \mathrm{l}$ & $39.8 \pm 9.6^{*}$ & $48.5 \pm 15.1$ & $62.3 \pm 8.8^{*}$ & $52.9 \pm 9.1$ \\
\hline
\end{tabular}

Comparisons between patients and controls (Mann-Whitney U test): N.S.

Comparisons within each group (responses after TRH and after rhEPO plus TRH; Wilcoxon test): ${ }^{\star} P<0.05$. 

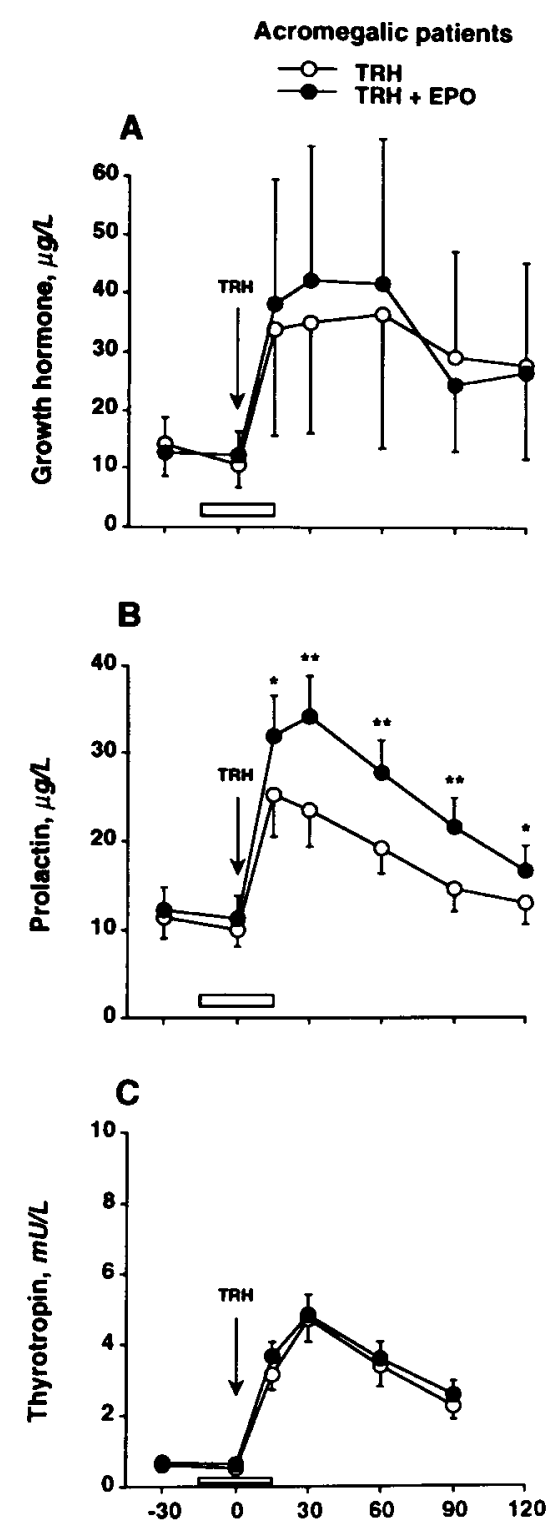
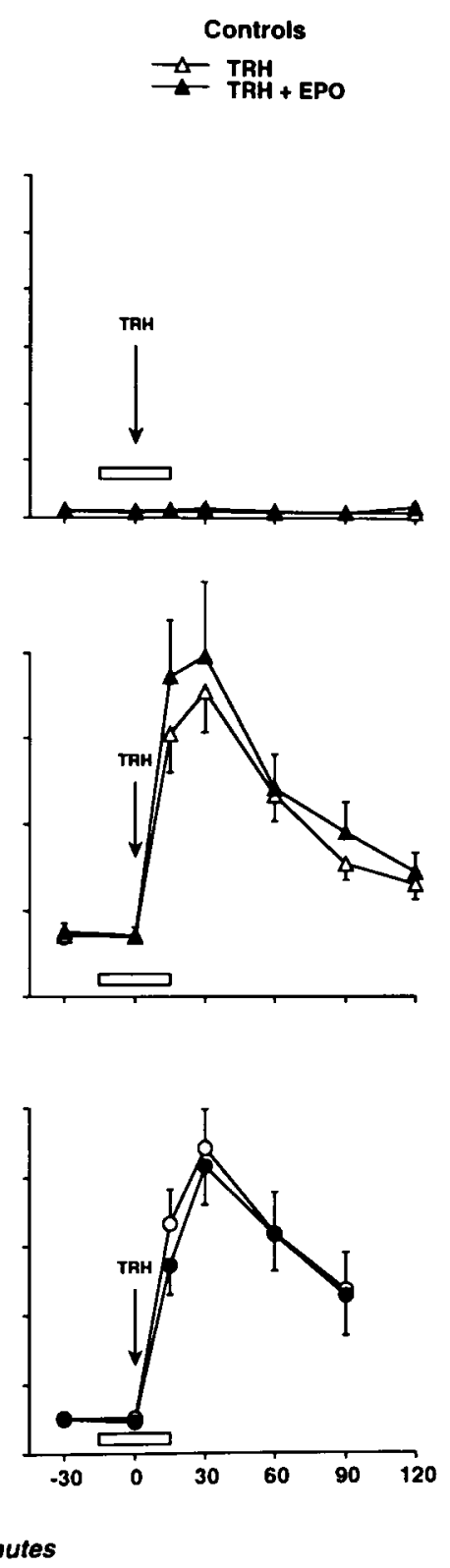

Figure $1 \mathrm{GH}(\mathrm{A}), \mathrm{PRL}(\mathrm{B})$ and TSH $(\mathrm{C})$ responses to stimulation with $\mathrm{TRH}(\mathrm{O}, \triangle)$ and rhEPO plus $\operatorname{TRH}(\bullet, \Delta)$ in 16 acromegalic patients $(\mathrm{O}, \mathbf{0}$; left-hand graphs) and 12 healthy controls $(\triangle, \mathbf{\Lambda}$; right-hand graphs). TSH responses were studied in 15 patients. Arrows indicate the times of TRH injection. Horizontal bars indicate the times of rhEPO infusion. Abscissa scale, time (min); ordinate scale, hormonal concentrations. Each point represents the mean \pm S.E.M. ${ }^{\star} P<0.05$, ${ }^{*} P<0.01$.
$(0.52 \pm 0.10 \mathrm{vs} 1.05 \pm 0.17 \mathrm{mU} / \mathrm{l}, P<0.01)$. In patients, these levels reached a peak of $4.85 \pm 0.63 \mathrm{mU} / \mathrm{l} 30 \mathrm{~min}$ after TRH stimulation. When this stimulus was injected during rhEPO infusion there were no significant modifications in the time or the magnitude (5.10 \pm $0.55 \mathrm{mU} / \mathrm{l}$ ) of the TSH peak (Fig. 1C, Table 2). TSH AUC obtained after rhEPO plus TRH stimulation were also very similar to values found after the injection of TRH (Table 2).

In the group of 12 normal volunteers, TRH injection was followed by an increase in TSH concentrations that reached a maximum of $8.83 \pm 1.12 \mathrm{mU} / \mathrm{l}$ after $30 \mathrm{~min}$. TRH administration during rhEPO infusion gave rise to a peak TSH concentration $(8.43 \pm 1.13 \mathrm{mU} / \mathrm{l})$ that did not differ from that found after TRH alone. The AUC for TSH secretion obtained in control subjects after rhEPO plus TRH stimulation did not differ from values obtained after injection of TRH alone (Table 2).

As shown in Table 2, control subjects exhibited higher values for TSH peaks and TSH AUC in comparison with patients after stimulation with TRH alone and also after rhEPO plus TRH infusion. On the other hand, no significant differences were observed in baseline TSH concentrations and its response to TRH or rhEPO plus TRH in patients or controls divided according to gender. No subjective side-effects were reported during the tests, either in control subjects or in patients with acromegaly. 


\section{Discussion}

The results of this work clearly show that acutely administered rhEPO has no influence on GH responses to TRH stimulation in a group of acromegalic patients, with 12 out of 16 subjects exhibiting a GH increase of at least twice the basal level when tested with TRH alone (2). As in other studies, the variability in the $\mathrm{GH}$ responses to TRH may be accounted for by the intrinsic secretory characteristics of each adenoma (14). Previous investigations by Ramírez et al. (12) have demonstrated that chronic therapy with rhEPO is accompanied by a disappearance of the paradoxical response of $\mathrm{GH}$ to TRH in hemodialyzed patients (12). Our group has reported that acute infusion of rhEPO also abolishes this paradoxical GH reaction in patients with chronic renal failure (13).

In uremic patients, this abolition of $\mathrm{GH}$ release after TRH has been attributed to a possible enhancement of hypothalamic somatostatin release or a reduction of the release of GHRH (13). However, the mechanisms underlying the paradoxical GH responses to TRH seem quite different in patients with acromegaly in relation to uremic patients. Firstly, the role of somatostatin in the regulation of TRH-stimulated GH release in acromegaly is less clear. Somatostatin may either inhibit (15) or fail to affect (16) the $\mathrm{GH}$ release after TRH in human $\mathrm{GH}$ tumor cells. In vivo, a blunting of the paradoxical GH response to TRH during high-dose $(1000 \mu \mathrm{g} / \mathrm{h})$ somatostatin infusion has been reported (17), although lowdose $(100 \mu \mathrm{g} / \mathrm{h})$ somatostatin infusion (18) did not modify the paradoxical GH response to TRH in acromegalic patients. These responses have also been shown to disappear in the majority of patients with acromegaly treated long-term with the long-acting somatostatin analogue octreotide (19-21). Interestingly, the acute increase in hypothalamic somatostatin tone caused by glucocorticoids did not modify the paradoxical $\mathrm{GH}$ response to $\mathrm{TRH}$ in acromegalic patients (14), although the glucocorticoid-induced increase in somatostatin tone is only speculative. Other studies have shown that cholinergic blockade with atropine is unable to suppress the $\mathrm{GH}$ response to TRH in patients with acromegaly (22). Hence, cholinergic pathways seem not to be involved in the paradoxical GH reaction to TRH in acromegaly (22). Lastly, it has been reported that endogenous opiate receptors do not play a major role in modulating $\mathrm{GH}$ secretion in acromegaly $(23,24)$, and that opioid peptides failed to affect TRH-induced stimulation of $\mathrm{GH}$ secretion in adenomatous human pituitary cells (25).

A direct pituitary stimulatory action of TRH has been postulated (26-28). In rats, it has been shown that TRH can elicit GH secretion from normal or tumoral somatotropic cells (29) and mRNA for the TRH receptor has been localized in somatotropes (30). Paradoxical GH responses to TRH have been observed in dispersed human GH-secreting adenomatous cells that probably express TRH receptors (31), and the disappearance of these responses after adenomectomy has been reported in acromegalic patients (27). The mechanism of action of TRH has been investigated in human GH-secreting adenomas in several in vitro studies $(26,32)$. The human TRH receptor, whose gene has been cloned, is a member of the G protein-coupled receptor family (33). Mutations in this receptor might be involved in the etiology of pituitary adenomas, although a recent study found that the TRH-receptor structure was normal in TSH-, PRL- and GH-secreting pituitary adenomas (34). A dedifferentiation of the receptors on the somatotropes, with a subsequent $\mathrm{GH}$ response to TRH, has also been proposed as a possible explanation for the TRH-induced $\mathrm{GH}$ release in acromegaly (25). These findings support the idea that the paradoxical $\mathrm{GH}$ reaction to TRH in acromegaly may be due to the presence of adenomatous tissue and that TRH may directly stimulate GH secretion at the adenoma level through interaction with specific receptors. In this setting, rhEPO seems to be unable to interfere with this hormone-receptor interaction.

TRH is considered to have no effect on GH secretion in healthy humans, and our results in healthy volunteers suggest that rhEPO does not exert any influence on these responses. However, abnormal GH responses to TRH have also been reported in patients with hypothyroidism (35), anorexia nervosa (36), diabetes mellitus (37), liver cirrhosis (38) and status epilepticus (39). Investigations of these conditions suggest that the paradoxical $\mathrm{GH}$ reaction to TRH may be a functional consequence of several pathological states characterized by altered somatostatin control of GH secretion.

Our results show that acute infusion of rhEPO does not modify PRL responses to TRH in normal subjects, but significantly enhances PRL secretion in normoprolactinemic acromegalic patients, irrespective of the gender of the subjects. Although no patient studied exhibited overt hyperprolactinemia, two had basal PRL levels higher than $20 \mu \mathrm{g} / \mathrm{l}(24$ and $28 \mu \mathrm{g} / \mathrm{l})$. It is possible that PRL secretion in these patients could in fact be of tumoral origin or due to hypothalamic-pituitary deafferentiation, since it has been reported that mixed $\mathrm{GH}-$ PRL-secreting adenomas do not always cause high serum levels of PRL (40). No relationship between baseline PRL concentrations and the effect of rhEPO on TRH-induced PRL release was found. Data obtained in controls are in agreement with results reported by Bernini et al. (41), who found no change in PRL responses to TRH after acute injection of rhEPO in normal subjects. Nevertheless, a normalization of the elevated PRL has been well established in uremic patients after chronic therapy with rhEPO (12, 42, 43). Discrepancies between our findings and those reported for uremic patients may be explained by the fact that uremic patients show elevated PRL levels, whereas the group of acromegalic patients studied here exhibit normal or near-normal PRL levels. In addition, 
distinct neuroregulatory pathways of PRL secretion may act in these two pathological conditions.

The mechanism of rhEPO action on prolactin secretion is not known. A direct action by the peptide on the physiological mechanism regulating PRL secretion in uremic patients seems unlikely (41), and a better oxygen supply due to the improvement of the anemia has been suggested as the causative factor of the PRLreducing effect observed in these patients. Our results in acromegalics suggest that a direct trophic action on rhEPO at the hypothalamic or pituitary levels might be possible. In fact, the effects of acutely administered rhEPO on GH responses to GHRH (11) and TRH (13) and on LH responses to GnRH (44) in uremic patients may not be explained by an elevation in hematocrit values.

A tentative explanation for our findings in acromegalic patients could be that rhEPO would interfere with the dopamine hypothalamic pathways, thus rendering lactotrophs more responsive to the stimulation with TRH. This action seems unlikely since, in acromegaly, dopaminergic stimulation inhibits PRL and GH release $(2,45)$ and we could not find any effect of rhEPO on GH responses. Other pathways, such as those mediated by serotonin, GABA, opioids and histamine, could also be involved. Therefore, the mechanism by which rhEPO can modulate PRL release in acromegalic patients remains unclear despite the present results.

We have also tested the effect of rhEPO on the TSH response to TRH in patients and controls. Baseline and TRH-stimulated TSH levels were significantly lower in acromegalics than in controls, as reported in other studies (46). Suppression of TSH levels in euthyroid acromegalics has been accounted for by a chronic suppression of TRH neurons by a compensatory hypersecretion of somatostatin (47), and by a GHstimulated increase in the conversion of T4 into T3 (48). TSH responses to its physiological releasing hormone are not influenced by acute infusion of rhEPO in acromegalic patients or in normal subjects. A similar finding was previously reported by our group in patients with chronic renal failure (13). In addition, no changes in basal (49) and TRH-stimulated (50) levels have been found in uremic patients after correction of the anemia by rhEPO therapy.

In summary, our findings show that acute rhEPO infusion cannot modify either the paradoxical $\mathrm{GH}$ reaction or the normal TSH release in response to TRH stimulation in patients with acromegaly. No effects of rhEPO were observed in controls for GH, TSH and PRL release after TRH administration. On the contrary, our data also show that, although the PRL-inhibiting effect of rhEPO is well known in uremic patients, acute administration of this peptide enhances TRH-stimulated prolactin release in normoprolactinemic patients with GH-secreting pituitary adenoma. A possible direct action at pituitary or hypothalamic level is suggested for such patients.

\section{Acknowledgements}

The authors are indebted to Ms Isabel Molina for her technical assistance.

\section{References}

1 Beck P, Parker ML \& Daughaday WH. Paradoxical hypersecretion of growth hormone in response to glucose. Journal of Clinical Endocrinology and Metabolism 196626 462-469.

2 Liuzzi A, Chiodini PG, Botalla L, Silvestrini F \& Müller EE. Growth hormone (GH)-releasing activity of TRH and GH-lowering effect of dopaminergic drugs in acromegaly: homogeneity in the two responses. Journal of Clinical Endocrinology and Metabolism 1974 $39871-876$.

3 Giustina A, Bodini C, Doga M, Schettino M, Pizzocolo G \& Giustina G. Galanin decreases circulating growth hormone levels in acromegaly. Journal of Clinical Endocrinology and Metabolism 199274 1296-1300.

4 Irie M \& Tsushima T. Increase of serum growth hormone concentrations following thyrotropin releasing hormone injection in patients with acromegaly or gigantism. Journal of Clinical Endocrinology and Metabolism 197235 97-100.

5 Rubin AL, Levin SR, Bernstein RI, Tyrrell JB, Noacco C \& Forsham $\mathrm{PH}$. Stimulation of growth hormone by luteinizing hormone releasing hormone in active acromegaly. Journal of Clinical Endocrinology and Metabolism 197337 160-162.

6 Pieters GFFM, Hermus ARMM, Smals AGH \& Kloppenborg PWC. Paradoxical responsiveness of growth hormone to corticotropinreleasing factor in acromegaly. Journal of Clinical Endocrinology and Metabolism 198458 560-562.

7 Groopman JE, Molina JM \& Scadden DT. Hematopoietic growth factors. Biology and clinical applications. New England Journal of Medicine 1989321 1449-1459.

8 Ramírez G, Bittle PA, Sanders H, Raab HAA \& Bercu BB. The effects of corticotropin and growth hormone releasing hormone on their respective secretory axes in chronic hemodialysis patients before and after correction of anemia with recombinant human erythropoietin. Journal of Clinical Endocrinology and Metabolism 199478 63-69.

9 Cremagnani L, Cantalamessa L, Orsatti A, Vigna L, Vallino F \& Buccianti G. Recombinant human erythropoietin (rhEPO) treatment potentiates growth hormone $(\mathrm{GH})$ response to growth hormone releasing hormone (GHRH) stimulation in hemodialysis patients. Clinical Nephrology 199339 282-286.

10 Díez JJ, Iglesias P, Sastre J, Méndez J, Selgas R \& Gómez-Pan A. Growth hormone responses to growth hormone-releasing hormone and clonidine before and after erythropoietin therapy in CAPD patients. Nephron $199674548-554$.

11 Cantalamessa L, Cremagnani L, Orsatti A, Vigna L \& Buccianti G. Increased growth hormone response to growth hormone-releasing hormone induced by erythropoietin in uraemic patients. Clinical Endocrinology 199134 85-89.

12 Ramírez G, Bittle PA, Sanders H \& Bercu BB. Hypothalamohypophyseal thyroid and gonadal function before and after erythropoietin therapy in dialysis patients. Journal of Clinical Endocrinology and Metabolism 199274 517-524.

13 Díez JJ, Iglesias P, Sastre J, Gómez-Pan A, Selgas R, Martínez-Ara J et al. Influence of erythropoietin on paradoxical responses of growth hormone to thyrotropin-releasing hormone in uremic patients. Kidney International 199446 1387-1391.

14 Giustina A, Doga M, Bresciani E, Bussi AR, Chiesa L, Misitano V et al. Effect of glucocorticoids on the paradoxical growth hormone response to thyrotropin-releasing hormone in patients with acromegaly. Metabolism 199544 379-383.

15 Le Dafniet M, Garnier P, Brandi AM, Bression D, Scherrer H, Racadot J et al. Interaction between somatostatin and TRH on growth hormone secretion in perfused human growth hormone tumor cells. Hormone Research 198521 235-239. 
16 Enjalbert A, Epelbaum J, Aranciba S, Tapia-Arancibia L, BluetPajot MT \& Kordon C. Reciprocal interactions of somatostatin with thyrotropin-releasing hormone and vasoactive intestinal peptide on prolactin and growth hormone secretion in vitro. Endocrinology $198211142-47$.

17 Gomez-Pan A, Tunbridge WMG, Duns A, Hall R, Besser GM, Coy DH et al. Hypothalamic hormone interaction in acromegaly. Clinical Endocrinology 19754 455-460.

18 Giustina G, Reschini E, Peracchi M, Cantalamessa L, Cavagnini F, Pinto $\mathrm{M}$ et al. Failure of somatostatin to suppress thyrotropin releasing factor and luteinizing hormone releasing factor induced growth hormone release in acromegaly. Journal of Clinical Endocrinology and Metabolism 197438 906-909.

19 Pieters CFFM, van Liessum PA, Smals AGH, van Gennep JA, Benraad TJ \& Kloppenborg PWC. Long-term treatment of acromegaly with Sandostatin (SMS 201-995). Acta Endocrinologica 1987 (Suppl) 286 9-18.

20 Pieters GFFM, Smals AEM, Smals AGH, van Gennep JA \& Kloppenborg PWC. The effect of minisomatostatin on anomalous growth hormone responses in acromegaly. Acta Endocrinologica $1987114537-542$.

21 Arosio M, Macchelli S, Rossi CM, Casati G, Biella O, Faglia G et al. Effects of treatment with octreotide in acromegalic patients - a multicenter Italian study. European Journal of Endocrinology 1995 133 430-439.

22 Watanobe H, Habu S, Nasushita R \& Takebe K. Lack of involvement of the cholinergic mechanism in vasoactive intestinal peptide- and peptide-histidine methionine-induced growth hormone $(\mathrm{GH})$ responses in acromegaly: comparison with the $\mathrm{GH}$ responses to thyrotropin-releasing hormone and GH-releasing hormone. Neuropeptides 199427 85-90.

23 Blankstein J, Reyes F, Winter J \& Faiman C. Failure of naloxone to alter growth hormone and prolactin levels in acromegalic and in hyperprolactinaemic patients. Clinical Endocrinology 197911 475-479.

24 Delitala G, Giusti M, Borsi L, Devilla L, Mazzochi G, Lotti G et al. Effects of a Met-enkephalin analogue and naloxone infusion on anterior pituitary hormone secretion in acromegaly. Hormone Research $19811588-98$.

25 Ishibashi M \& Yamaji T. Direct effects of catecholamines, thyrotropin-releasing hormone, and somatostatin and growth hormone and prolactin secretion from adenomatous and nonadenomatous human pituitary cells in culture. Journal of Clinical Investigation 198473 66-78.

26 Ishibashi M \& Yamaji T. Effect of thyrotropin-releasing hormone and bromoergocriptine on growth hormone and prolactin secretion in perfused pituitary adenoma tissues of acromegaly. Journal of Clinical Endocrinology and Metabolism 1978471251 1256.

27 Faglia G, Paracchi A, Ferrari RC \& Beck-Peccoz P. Evaluation of the results of trans-sphenoidal surgery in acromegaly by assessment of the growth hormone responses to thyrotropinreleasing hormone. Clinical Endocrinology 1978 8 373-380.

28 Shibasaki T, Hotta M, Masuda A, Imaki T, Obara N, Hizuka N et al. Studies on the response of growth hormone $(\mathrm{GH})$ secretion to GH-releasing hormone, thyrotropin-releasing hormone, gonadotropin-releasing hormone, and somatostatin in acromegaly. Journal of Clinical Endocrinology and Metabolism 198663 167173.

29 Szabo M, Stachura ME, Paleologos N, Bybee DE \& Frohman LA. Thyrotropin-releasing hormone stimulates growth hormone release from the anterior pituitary of hypothyroid rats in vitro. Endocrinology 1984114 1344-1351.

30 Konaka S, Yamada M, Satoh T, Ozawa H, Watanabe E, Takata K et al. Expression of thyrotropin-releasing hormone (TRH) receptor mRNA in somatotrophs in the rat anterior pituitary. Endocrinology $1997138817-830$.

31 Hanew K, Utsumi A. Tanaka A. Ikeda H \& Yokogoshi Y. Secretory mechanisms of growth hormone $(\mathrm{GH})$-releasing peptide-, $\mathrm{GH}$ releasing hormone-, and thyrotropin-releasing hormone-induced
GH release in patients with acromegaly. Journal of Clinical Endocrinology and Metabolism 199883 3578-3583.

32 Somjen D, Tordjman K, Greenman Y, Kohen F, Ouaknine GE \& Stern N. TRH is a tonic secretagogue in growth hormone secreting but not in nonfunctioning pituitary tumors. Journal of Endocrinological Investigation 199922 104-108.

33 Yamada M, Monden T, Satoh T, Satoh N, Murakami M, Iriuchijima $\mathrm{T}$ et al. Pituitary adenomas of patients with acromegaly express thyrotropin-releasing hormone receptor messenger RNA: cloning and functional expression of the human thyrotropin-releasing hormone receptor gene. Biochemical and Biophysical Research Communications 1993195 737-745.

34 Faccenda E, Melmed S, Bevan JS \& Eidne KA. Structure of the thyrotrophin-releasing hormone receptor in human pituitary adenomas. Clinical Endocrinology 199644 341-347.

35 Collu R, LeBoeuf G, Letarte J \& Ducharme JR. Increase in plasma growth hormone levels following thyrotropin-releasing hormone injection in children with primary hypothyroidism. Journal of Clinical Endocrinology and Metabolism 197744 743-747.

36 Maeda K, Kato Y, Yamaguchi N, Chihara K, Ohgo S, Iwasaki Y et al. Growth hormone release following thyrotropin releasing hormone injection into patients with anorexia nervosa. Acta Endocrinologica 197681 1-8.

37 Dasmahapatra A. Urdanavia E \& Cohen MP. Growth hormone response to thyrotropin-releasing hormone in diabetes. Journal of Clinical Endocrinology and Metabolism 198152 859-862.

38 Zanoboni A \& Zanoboni-Muciacca W. Elevated basal growth hormone levels and growth hormone response to TRH in alcoholic patients with cirrhosis. Journal of Clinical Endocrinology and Metabolism 197745 576-578.

39 Lindbom U, Hulting AL \& Tomson T. Paradoxical GH response to TRH during status epilepticus in man. European Journal of Endocrinology $1999140307-314$.

40 Bassetti M, Spada A, Arosio M, Vallar L, Brina M \& Giannattasio G. Morphological studies on mixed growth hormone (GH)- and prolactin (PRL)-secreting human pituitary adenomas. Coexistence of GH and PRL in the same secretory granule. Journal of Clinical Endocrinology and Metabolism 198662 1093-1100.

41 Bernini GP, Mariotti F, Brogi G, Cerri F, Santoni M, Ciardella F et al. Effect of erythropoietin administration on prolactin secretion in normal subjects. Nephron $199365522-526$.

42 Schaefer RM, Kokot F, Kürner B, Zech M \& Heidland A. Normalization of elevated prolactin levels in hemodialysis patients on erythropoietin. Nephron 198850 400-401.

43 Kokot F, Wiecek A, Schmidt-Gayk H, Marcinkowski W, Gilge U, Heidland A et al. Function of endocrine organs in hemodialyzed patients of long-term erythropoietin therapy. Artificial Organs $199519428-435$.

44 Díez JJ, Iglesias P, Bajo MA, de Alvaro F \& Selgas R. Effects of erythropoietin on gonadotropin responses to gonadotropinreleasing hormone in uremic patients. Nephron 199777 169175.

45 Chiodini PG, Liuzzi A, Cremascoli G, Botalla L \& Silvestrini F. Inhibitory effect of dopaminergic stimulation on GH release in acromegaly. Journal of Clinical Endocrinology and Metabolism 1974 38 200-206.

46 Merola B, Colao A, Cataldi M, Rossi E, Longobardi S, Caruso E et al. Serum thyrotropin response to combined arginine and thyrotropin-releasing hormone administration provides evidence for an altered somatostatinergic tone in acromegaly. Hormone Research $1992377-13$.

47 Cobb WE, Reichlin S \& Jackson IMD. Growth hormone secretory status is a determinant of the thyrotropin response to thyrotropinreleasing hormone in euthyroid patients with hypothalamicpituitary disease. Journal of Clinical Endocrinology and Metabolism $198152234-239$.

48 Jorgensen JOL, Pedersen SA, Laurberg P, Weeke J, Skakkebaek NE \& Christiansen JS. Effects of growth hormone therapy on thyroid function of growth hormone-deficient adults with and without concomitant thyroxine-substituted central hypothyroidism. 
Journal of Clinical Endocrinology and Metabolism 1989691127 1132 .

49 Díez JJ, Iglesias P, Sastre J, Aguilera A, Bajo MA, Méndez J et al. Long-term effects of recombinant human erythropoietin therapy on growth hormone secretion in uremic patients undergoing peritoneal dialysis. Metabolism 199948 210-216.

50 Kokot F, Wiecek A, Grzeszczak W, Klepacka J, Klin M \& Lao M.
Influence of erythropoietin treatment on endocrine abnormalities in haemodialized patients. Contributions to Nephrology 198976 257-272.

Received 14 December 1999

Accepted 28 March 2000 